\title{
Diatomite releases silica during spirit filtration
}

\author{
J. Gómez ${ }^{\text {a,* }}$, M.L.A. Gil ${ }^{\text {b }}$ N. de la Rosa-Fox ${ }^{c}$, M. Alguacil ${ }^{\mathrm{d}}$ \\ ${ }^{a}$ Department of Chemical Engineering and Food Technology, Faculty of Sciences, University of Cádiz, Campus Río San Pedro, PB 40, 11510 Puerto Real, Spain \\ ${ }^{\mathrm{b}}$ Department of Chemical Physics, Faculty of Sciences, University of Cádiz, Campus Río San Pedro, PB 40, 11510 Puerto Real, Spain \\ ${ }^{\mathrm{C}}$ Department of Physics of Condensed Matter, Faculty of Sciences, University of Cádiz, Campus Río San Pedro, PB 40, 11510 Puerto Real, Spain \\ ${ }^{\mathrm{d}}$ Department of Molecular Biology and Biochemical Engineering, University of Pablo de Olavide Building 22, 3rd floor, Road to Utrera, km 1, 41013 Sevilla, Spain
}

\section{A R T I C L E I N F O}

\section{Article history:}

Received 4 September 2013

Received in revised form 11 February 2014

Accepted 27 February 2014

Available online 12 March 2014

\section{Keywords:}

Diatomite

Filtration

Filter Aid

Spirit

Brandy de Jerez

Silica

Silicon

Calcium

\begin{abstract}
A B S T R A C T
The purpose of this study was to ascertain whether diatomite is an inert filter aid during spirit filtration. Surely, any compound with a negative effect on the spirit composition or the consumer's health could be dissolved. In this study different diatomites were treated with $36 \%$ vol. ethanol/water mixtures and the amounts and structures of the extracted compounds were determined. Furthermore, Brandy de Jerez was diatomite- and membrane-filtered at different temperatures and the silicon content was analysed. It was found that up to $0.36 \%$ by weight of diatomite dissolved in the aqueous ethanol and amorphous silica, in the form of hollow spherical microparticles, was the most abundant component. Silicon concentrations in Brandy de Jerez increased by up to $163.0 \%$ after contact with diatomite and these changes were more marked for calcined diatomite. In contrast, reductions of more than $30 \%$ in silicon concentrations were achieved after membrane filtration at low temperatures.
\end{abstract}

(c) 2014 Elsevier Ltd. All rights reserved.

\section{Introduction}

Diatomite is the most widely used filter aid in wine and spirit filtration because of its low price and good filtering behaviour. Diatomite is a siliceous rock composed of fossilized skeletons of diatoms with numerous perforations and it mainly consists of opal or hydrous silica $\left(\mathrm{SiO}_{2} \cdot n \mathrm{H}_{2} \mathrm{O}\right)$ (Kadey, 1975). Diatomite is found in large deposits of marine or lacustrine origin that were formed millions of years ago (Inglethorpe, 1993). After mining, diatomite is crushed, milled, dried and classified into different sizes. The resulting materials are grey in colour and an the average particle size is in the range $1.5-2.5 \mu \mathrm{m}$. Larger particle sizes can be obtained by heating diatomite to $900-1100{ }^{\circ} \mathrm{C}$ in large rotary kilns to cause incipient fusion. This process is followed by milling and re-classification and the particle size typically increases to $2.5-5.0 \mu \mathrm{m}$. These calcined grades are pink in colour due to oxidation of iron. Even larger sizes, from 7.0 to $22.0 \mu \mathrm{m}$, can be obtained by further size adjustment achieved by the addition of a flux such as sodium carbonate prior to the calcination step. This produces fines agglomeration and the flux-calcined grades are white in colour due to the conversion of iron to sodium/aluminium/iron silicate complexes (Wang, 2006).

\footnotetext{
* Corresponding author. Tel.: +34 956016382; fax: +34 956016411. E-mail address: juangomez.benitez@uca.es (J. Gómez).
}

Diatom skeletons seem to be amorphous by optical microscopy, but X-ray diffraction shows a broad band in the region of the main cristobalite peak (Kadey, 1975). X-ray diffraction analyses reveal that natural diatomite prior to treatment consists of amorphous phases with traces of quartz, feldspar, cristobalite, trydimite and $3-8 \%$ of structural water (Martinovic, Vlahovic, Boljanac, \& Pavlovic, 2006). However, processing of diatomite produces changes in its structure due to the loss of combined water, degradation of valves during incipient fusion and partial conversion of amorphous silica to cristobalite.

Crystalline silicas such as quartz, trydimite or cristobalite have very low solubility in water but amorphous silica is much more soluble. At $25^{\circ} \mathrm{C}$ the solubility is $5-7 \mathrm{mg} / \mathrm{L}$ for quartz and $100-140 \mathrm{mg} / \mathrm{L}$ for amorphous silica (Iler, 1979) and this increases in a linear manner with temperature (Alexander, Heston, \& Iler, 1954; Gunnarsson \& Arnorsson, 2000). The solubility of silica is very dependent on $\mathrm{pH}$. From acidic $\mathrm{pH}$ values the solubility varies very little up to $\mathrm{pH}$ 8-9 and it then increases exponentially beyond these values at more alkaline $\mathrm{pH}$ due to the formation of silicate ions (Martin, 2007; Seidel, Liibbus, Vogelsberger, \& Sonnefeld, 1997). The presence of other salts in solution reduces the solubility of amorphous silica (Marshall \& Warakomski, 1980). Consequently, from the point of view of silica, diatomite has always been considered as an inert filter aid and studies into the release of silica from diatomite during filtration have not been published to date. 
Brandy is a spirit that is produced from wine distillate and it is aged for at least six months in oak barrels (European-Union, 2008). Brandy de Jerez is a Protected Geographical Indication that is produced in Andalucía (South Spain) (Junta-de-Andalucia, 2005; Schwarz, Rodriguez, Guillen, \& García, 2011). Furthermore, the silicon contents of foods and alcoholic beverages have been widely determined because silicon intake may be beneficial for growth and the development of bone and other connective tissue (Jugdaohsingh et al., 2004; Jugdaohsingh, O'Connell, Sripanyakorn, \& Powell, 2006). Levels of Si in wines lie in the range 7-23 mg/L (Bauer, Hinkel, Neeb, Eichler, \& Eschnauer, 1995; Interesse, Lamparelli, \& Alloggio, 1984; Powell et al., 2005) and the contribution to daily $\mathrm{Si}$ intake is $2-4 \%$ depending on the volumes consumed. Si levels in spirits are much lower (average $1.3 \mathrm{mg} / \mathrm{L}$ ) and intakes of these beverages are irrelevant in terms of dietary Si exposure (Jugdaohsingh et al., 2004).

The dissolution of diatomaceous silica in oceans is a wellknown process in the environment because the high productivity of diatoms requires a very efficient dissolution of diatomaceous frustules after the death of organisms in order to regenerate available $\mathrm{Si}(\mathrm{OH})_{4}$ (Van Cappellen \& Qiu, 1997). In aqueous solution, silica generates silicic acid, which is not particularly stable and can undergo a succession of dehydration polymerizations to condense into particles and colloids (Iler, 1979). Insoluble silica is formed by highly polymerized molecules that form spherical particles that are 1-100 nm in size (Martin, 2007). The aim of the study reported here was to evaluate whether the dissolution of silica could occur in diatomite spirit filtration, considering the instability of silica, and its possible effect on the subsequent stability of the filtered product.

Moreover, the maximum concentrations of calcium found in spirits such as whisky, rum and brandy are about $10 \mathrm{mg} / \mathrm{L}$ and all alcoholic and non-alcoholic drinks can contribute $10 \%$ of the recommended daily intake of calcium (Jodral-Segado, NavarroAlcorcón, López-García de la Serrana, \& López-Martínez, 2003). The concentrations of calcium in brandy are generally in the range 1-5 $\mathrm{mg} / \mathrm{L}$ and higher concentrations can cause stability problems (Gómez-Benítez, 1992).

The aim of the work described here was to study the dissolution of silicon and calcium during diatomite brandy filtration and to evaluate the supposed inertness of diatomite.

\section{Materials and methods}

\subsection{Diatomites and dissolution tests}

Two commercial samples of each grade (calcined and flux calcined) of diatomites supplied by two different international manufacturers were used. The grades were selected as they are the most commonly used materials in brandy filtration.

Dissolution tests were carried out to determine the contents of compounds present in diatomite that are soluble in an ethanol/ water mixture with an alcohol strength similar to that of brandy (36\% vol.). Ethanol (96\% v/v PA-ACS) and Milli-Q osmosis water were used in all experiments. The diatomite ( $10 \mathrm{~g})$ was added to $200 \mathrm{~mL}$ of ethanol/water mixture (36\% vol.) and the mixture was stirred with a magnetic stirrer for $30 \mathrm{~min}$ and separated by centrifugation. The cleaning process was repeated two more times and the extracts were collected, evaporated to dryness and weighed.

\subsection{X-ray diffraction (XRD) and X-ray fluorescence (XRF) analysis}

XRD experiments were performed on a Bruker diffractometer (D8 Advance) with a graphite monochromator and $\mathrm{Cu} \mathrm{K} \alpha$ radiation (wavelength $1.54 \AA$ ). The intensities were measured in a $2 \theta$ range
Table 1

Quantitative composition of diatomite in soluble compounds.

\begin{tabular}{|c|c|c|c|c|c|c|}
\hline \multicolumn{5}{|c|}{ Diatomite grade } & \multicolumn{2}{|c|}{ Soluble compounds } \\
\hline \multicolumn{7}{|c|}{$\begin{array}{l}\text { (a) Diatomite content in soluble compounds in water/ethanol mixture ( } 36 \% \text { vol.). } \\
\text { Values in\% by weight }\end{array}$} \\
\hline \multicolumn{4}{|c|}{ Calcined } & \multicolumn{3}{|c|}{$0.36 \pm 0.021$} \\
\hline \multicolumn{4}{|c|}{ Flux calcined } & \multicolumn{3}{|c|}{$0.23 \pm 0.014$} \\
\hline \multicolumn{7}{|c|}{ (b) Quantitative analysis of diatomite extract. Values in\% by weight } \\
\hline $\mathrm{SiO}_{2}$ & $\mathrm{SO}_{4}$ & $\mathrm{Na}_{2} \mathrm{O}$ & $\mathrm{CaO}$ & $\mathrm{P}_{2} \mathrm{O}_{5}$ & $\mathrm{~V}_{2} \mathrm{O}_{5}$ & $\mathrm{Cl}$ \\
\hline 31.2 & 29.2 & 16.2 & 8.5 & 7.28 & 2.50 & 1.26 \\
\hline $\mathrm{CuO}$ & $\mathrm{MgO}$ & $\mathrm{Al}_{2} \mathrm{O}_{3}$ & $\mathrm{~K}_{2} \mathrm{O}$ & $\mathrm{Fe}_{2} \mathrm{O}_{3}$ & $\mathrm{Cr}_{2} \mathrm{O}_{3}$ & $\mathrm{MoO}_{3}$ \\
\hline 1.11 & 1.09 & 0.603 & 0.501 & 0.238 & 0.194 & 0.158 \\
\hline
\end{tabular}

$\left(5-80^{\circ}\right)$ with a step of $0.2^{\circ}$ and a counting time of $1 \mathrm{~s}$ per step. All spectra were registered at room temperature. The spectra of the commercial diatomites were compared with those of the same samples after extraction and the corresponding dry extract from the dissolution test described in Section 2.1. Crystallographic phases were identified using the software Diffrac-plus EVA from Bruker-AXS. Quantitative diatomite elemental composition was analysed using a Bruker-S4Pioneer dispersive X-ray wavelength (WD XRF) fluorescence spectrometer with a total power of $4 \mathrm{~kW}$.

\subsection{Scanning electron microscopy (SEM) and energy dispersive X-ray spectroscopic analysis (EDX)}

Dry diatomite extracts were morphologically characterized by SEM and EDX techniques using a Quanta 2000 scanning electron microscope with a $30 \mathrm{kV}$ acceleration voltage. Prior to analysis the samples were gold-coated on carbon tapes with a sputtering device by applying $15 \mathrm{~mA}$ during $100 \mathrm{~s}$.

\subsection{IR analysis}

The chemical bonds of the materials under investigation were analysed by Fourier Transform Infrared spectrophotometry (FTIR). Spectra were obtained from powdered tablets using a Shimadzu FTIR-8400S spectrophotometer $\left(4 \mathrm{~cm}^{-1}\right.$ resolution) in the range $4000-648 \mathrm{~cm}^{-1}$. Experiments were also carried out in attenuated total reflection mode (ATR).

\subsection{Si and Ca analysis}

Si and Ca analysis was carried out by Inductively Coupled Plasma Atomic Emission Spectroscopy (ICP-AES), without sample treatment, using the Iris Intrepid model from Thermo Elemental.

\subsection{Thermogravimetric analysis}

Thermograms were registered from 25 to $1000{ }^{\circ} \mathrm{C}$ at a rate of $10^{\circ} \mathrm{C} / \mathrm{min}$ in a SETSYS $16 / 18$ SETARAM microbalance with an accuracy of $0.1 \mu \mathrm{g}$. The balance was equipped with an Ar vented tubular furnace. Analyses were performed in a static air atmosphere with He as carrier gas. Direct and derivative weight losses, (TG) and (DTG) respectively, were recorded. Air buoyancy correction was applied by recording a baseline with an empty crucible under the same conditions as in experiments.

\subsection{Brandy samples and filtration}

The experiments were designed to evaluate silica dissolution from diatomite used as a filter aid during brandy filtration. The influence of temperature was also assessed and a comparison with membrane filtration was made. Brandy de Jerez (36\% vol.) was used in all filtration tests, which were carried out in a winery in the Jerez region (Southern Spain) during the period January-June 

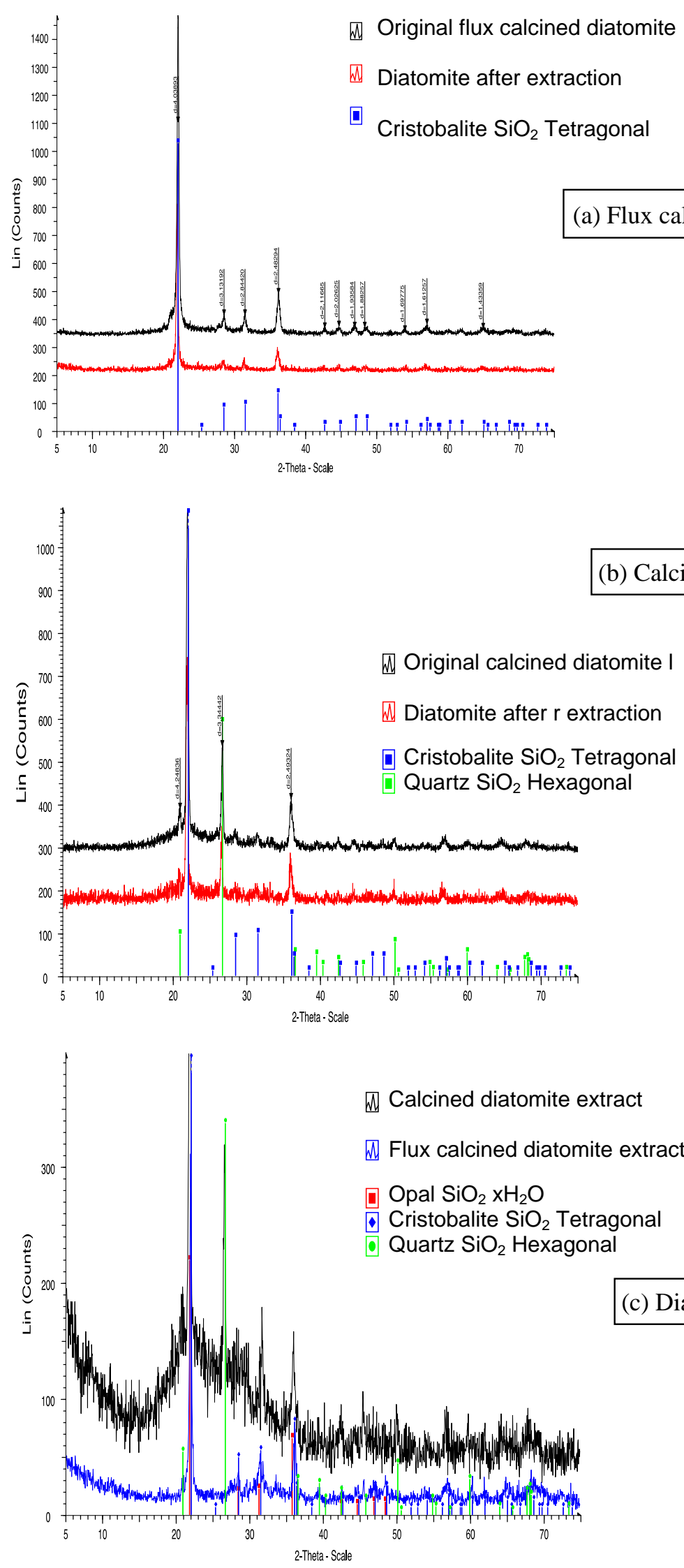

(a) Flux calcined diatomite

(b) Calcined diatomite

Fig. 1. XRD patterns.

2012. A Stella Meta Filter with a filtration surface of $20 \mathrm{~m}^{2}$ was used in conjunction with a mixture of $50 \%$ calcined and $50 \%$ flux calcined diatomite and a dose of $0.46 \mathrm{~g} / \mathrm{L}$ as filter aid. A tangential filter (Pall Oenoflow XL A Series) with 5 modules of polyvinylidene 

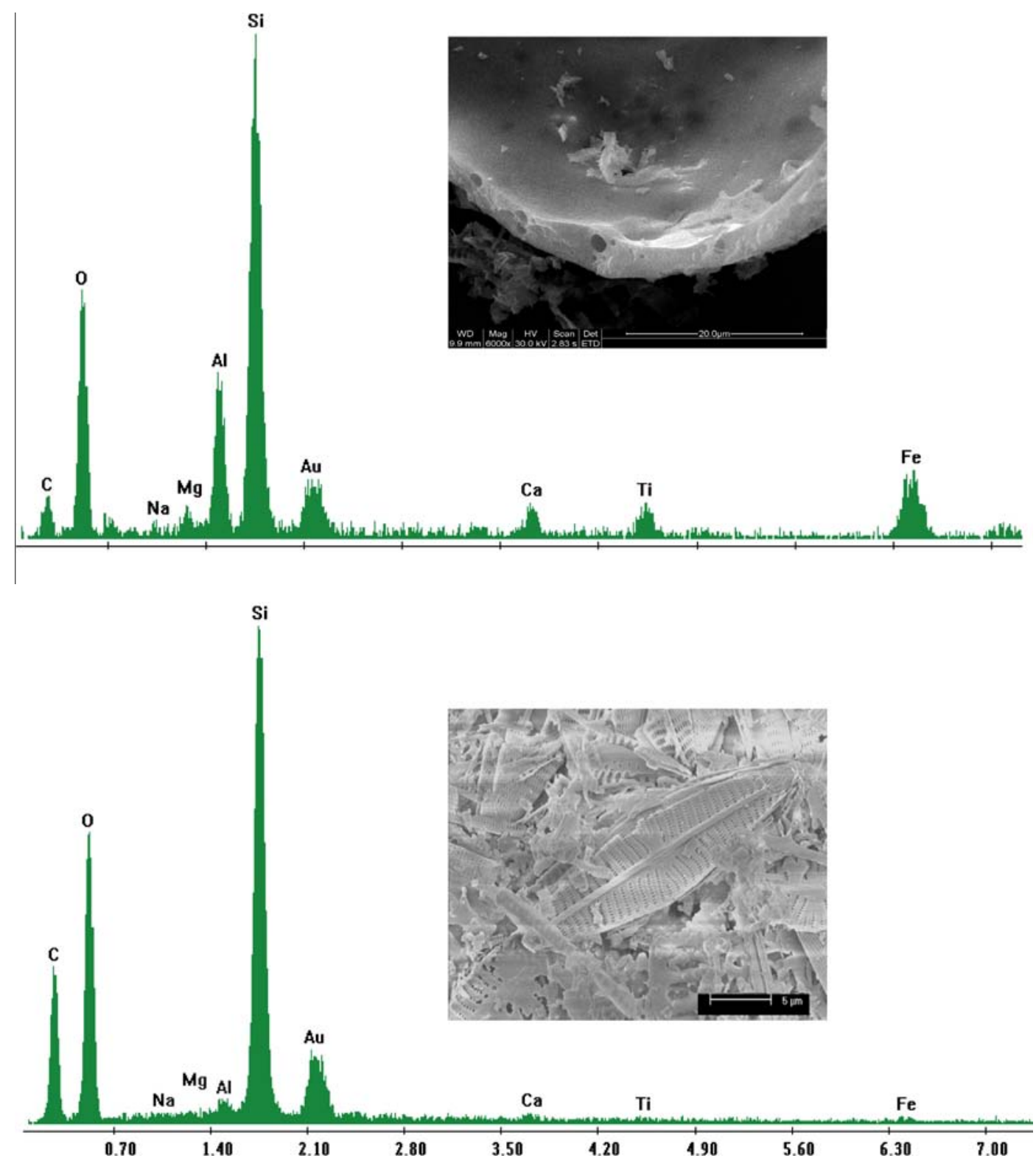

Fig. 2. EDX of diatomite extracts. C: carbon; O: oxygen; Na: sodium; Mg: magnesium; Al: aluminium; Si: silicon; Ayu: gold; Ca: calcium; Ti: titanium; Fe; iron.

fluoride membrane and yielding $50-75 \mathrm{hL} / \mathrm{h}$ was also employed. In both cases tests were carried out at 25,8 and $0{ }^{\circ} \mathrm{C}$. Furthermore, samples of the same brandy were treated separately with different grades of diatomite on a laboratory scale at 25 and $8{ }^{\circ} \mathrm{C}$ with the same total doses as used in the industrial filtration.

\section{Results and discussion}

\subsection{Soluble compounds in ethanol/water solution}

It can be seen from the results in Table 1a that diatomite contained a considerable amount of compounds that were soluble in ethanol/water (36\% vol.). The quantity of soluble compounds was appreciably higher for the calcined grade $(0.36 \%)$ than for the flux calcined grade $(0.2 \%)$, a finding that is consistent with the different particle sizes. However, the results for both of these samples are much lower than the $2 \%$ accepted in the International Oenological Codex for soluble diatomite products in dilute acids (OIV, 2006). It should also be noted that diatomite extracts in ethanol/water appeared cloudy from the beginning of the experiments, especially in the case of the calcined grade, and this cloudiness increased during evaporation.

\subsection{XRD analysis of diatomites and dry extracts}

X-ray diffraction patterns of the crystalline phases of diatomites before and after extraction are shown in Fig. 1a and b along with the corresponding phases of pure cristobalite and quartz. The peaks detected correspond to the cristobalite phase in the original flux calcined diatomite (black line in Fig. 1a), while the X-ray pattern for the calcined diatomite showed a crystalline quartz phase in addition to the cristobalite peaks (black line in Fig. 1b). Diatomites after extraction with the ethanol/water mixture (36\% vol.) showed lower peak intensities (red lines), indicating that some cristobalite and quartz had dissolved during the extraction. The X-ray patterns of the dry extracts of both diatomites are shown in Fig. 1c. It can be seen that the flux calcined diatomite extract appears to be mainly crystalline and this corresponds to cristobalite. 
However, the calcined diatomite extract, in addition to the crystalline phases of cristobalite and quartz, also showed a broad halo at around $21^{\circ}$, indicating the presence of an amorphous phase that is probably due to extracted amorphous silica. Overall, there is good agreement between the patterns obtained for the diatomites and their extracts.

\subsection{SEM and EDX of dry extracts}

Evaluation of the sediment by scanning electron microscopy showed numerous small spheres. The micrograph of a $100 \mu \mathrm{m}$ diameter particle covered with diatoms is shown in Image 1. This particle was obtained during the extraction process and some holes can be observed in the surface, which suggests a porous and hollow structure as described previously (Park, Kim, \& Park, 2008) for silica particles. Indeed, spherical silica nano and microparticles with empty structures are very common in silica technology because of their numerous applications in, for example, drug storage/release and catalysis (Liangjuan \& Junhui, 2013) and the formation of such particles in ethanol/water mixtures has been described (Chan, Hyung, Sujin, Dae, \& Seung-Ho, 2012). Furthermore, this hollow structure was confirmed by Image 2, which shows the micrograph of a broken hollow particle with a porous wall that is around 4-6 $\mu \mathrm{m}$ thick, as shown in the inset. The conchoidal wall fracture confirms the amorphous structure of the particle and this is consistent with the XRD patterns shown in Fig. 1c. The compositions of the sphere and diatomite were compared by EDX analysis (see Fig. 2). It can be seen that silicon was the major component of both particles and this result is in agreement with the information outlined in Section 3.2. Furthermore, these particles also contained $\mathrm{Mg}, \mathrm{Al}, \mathrm{Ca}$ and $\mathrm{Fe}$, which are typical constituents of silicates, and their peaks for the particle are much higher than those for diatomite, which reveals that these components are concentrated during the extraction. Finally, the presence of the Au and Ti peaks is a consequence of the gold-coating treatment on the tape.

\subsection{IR analysis of dry extracts}

The two diatomite extracts showed similar IR spectra (Fig. 3a and b). In these spectra, the broad and sharp bands centred at $c a$. 1075 and $795 \mathrm{~cm}^{-1}$ are due to the $\mathrm{Si}-\mathrm{O}-\mathrm{Si}$ in plane vibration (asymmetric stretching), which is characteristic of silica. Additionally, the broad bands in the regions 3280-3330 and 1634$1646 \mathrm{~cm}^{-1}$ are generated, respectively, by the $\mathrm{OH}$ vibration and bending modes of the physically adsorbed $\mathrm{H}_{2} \mathrm{O}$ (Fatoni, Koesnarpadi, \& Hidayati, 2010; Wen-Tien, Chi-Wei, \& Kuo-Jong, 2006). Consequently, the IR spectra are consistent with the presence of silica and some absorbed water in the diatomite extracts.

\subsection{X-ray fluorescence (XRF) analysis}

It can be seen from the results in Table $1 \mathrm{~b}$ that silica was the most abundant compound in the extract, at more than $30 \%$ by weight. The results in Table $1 \mathrm{~b}$ all correspond to oxides because of the changes that occur during sample drying and heating. The calcium and sodium oxide concentrations are consistent with that of $\mathrm{SO}_{4}$, suggesting that these elements are present as sulphates. Small amounts of copper, iron and aluminium oxides were also found and similar results were reported previously (Ruzic \& Puskas, 2001). Furthermore, heavy metals such as vanadium (2.5\%) and chromium (0.194\%) oxides were also discovered and these are recognized as toxic (Dayan \& Paine, 2001; Rodríguez-Mercado \& Altamirano-Lozano, 2006). (a)

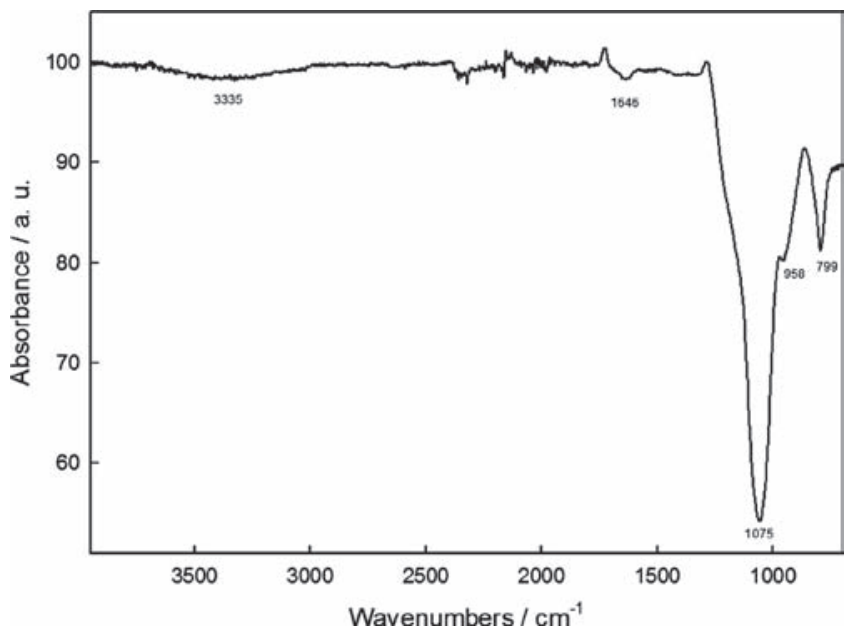

(b)

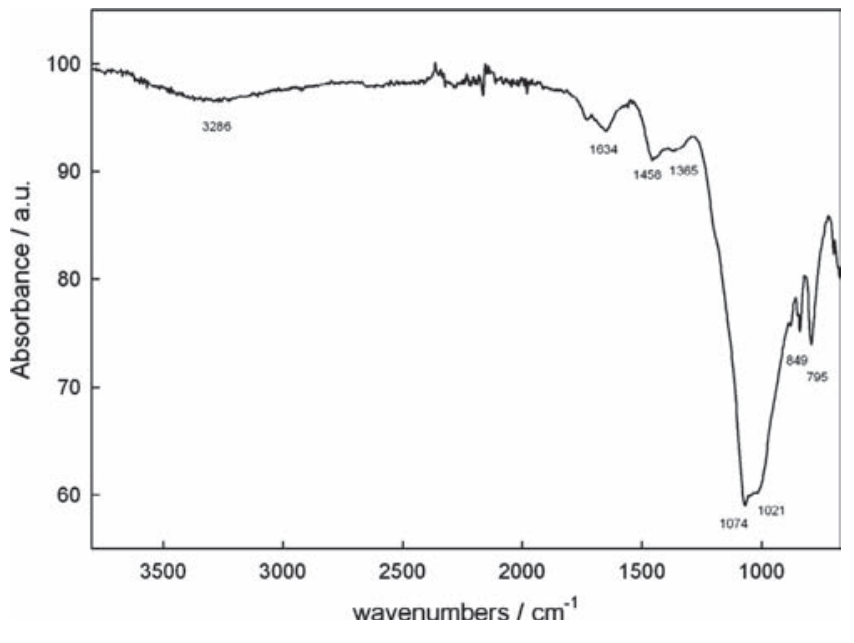

Fig. 3. IR spectra of diatomite water/alcohol extracts. (a) Calcined diatomite and (b) flux calcined diatomite.

\subsection{Silica and calcium dissolved by brandy}

Brandy contained Si and Ca before treatment but the concentrations of these elements increased appreciably after contact with diatomite in the laboratory tests and during industrial filtration (see results in Table 2). The concentrations of calcium are in agreement with those reported previously in Brandy de Jerez (Cameán, Moreno, López-Artíguez, Repetto, \& González, 2001) and in brandy and international spirits such as rum and whiskey (Ibanez, Carreon-Alvarez, Barcena-Soto, \& Casillas, 2008). However, the initial silicon concentrations measured in brandy are about one tenth of those determined in spirits (Jugdaohsingh et al., 2004) and this suggests a certain degree of unsaturation in silica. Additionally, the calcined grade of diatomite released more Si and Ca than the flux calcined grade. The increases in Si concentrations in laboratory tests at ambient temperature for the two diatomites were $163.0 \%$ and $42.4 \%$, respectively, and the increases in Ca concentrations were $56.9 \%$ and $33.6 \%$, respectively. The more marked increases in silica can be related to its unsaturation state in this molecule. The different behaviours of calcined and flux calcined diatomite are as one would expect considering their particle sizes and the increases in concentration in the laboratory tests were appreciably lower at lower temperatures ( $76.1 \%$ and $30.4 \%$ for $\mathrm{Si}$, respectively). 
Table 2

Analysis of $\mathrm{Si}$ and $\mathrm{Ca}$ in brandy.

\begin{tabular}{|c|c|c|c|c|c|}
\hline \multirow[t]{2}{*}{ Sample treatment } & \multirow[t]{2}{*}{ Temperature $\left({ }^{\circ} \mathrm{C}\right)$} & \multicolumn{2}{|l|}{$\mathrm{Si}$} & \multicolumn{2}{|l|}{$\mathrm{Ca}$} \\
\hline & & Concentration $(\mu \mathrm{g} / \mathrm{L})$ & Variation $^{\mathrm{a}}(\%)$ & Concentration (mg/L) & Variation $^{\mathrm{a}}(\%)$ \\
\hline Control & & 184 & - & 1.37 & - \\
\hline \multicolumn{6}{|l|}{ Laboratory } \\
\hline Flux calcined diatomite & 25 & 262 & 42.4 & 1.83 & 33.6 \\
\hline Calcined diatomite & 25 & 484 & 163.0 & 2.15 & 56.9 \\
\hline Flux calcined diatomite & 8 & 240 & 30.4 & 1.75 & 27.7 \\
\hline Calcined diatomite & 8 & 324 & 76.1 & 1.92 & 40.1 \\
\hline \multicolumn{6}{|l|}{ Industrial scale } \\
\hline Diatomite filtration & 25 & 242 & 31.5 & 1.8 & 31.3 \\
\hline Diatomite filtration & 8 & 220 & 19.6 & 1.81 & 32.1 \\
\hline Diatomite filtration & 0 & 213 & 15.8 & 1.35 & -1.5 \\
\hline Membrane filtration & 25 & 166 & -9.8 & 1.31 & -4.3 \\
\hline Membrane filtration & 8 & 143 & -22.3 & 1.03 & -24.8 \\
\hline Membrane filtration & 0 & 122 & -33.7 & 0.92 & -32.8 \\
\hline
\end{tabular}

All results are the average of two tests.

a In relation to control.

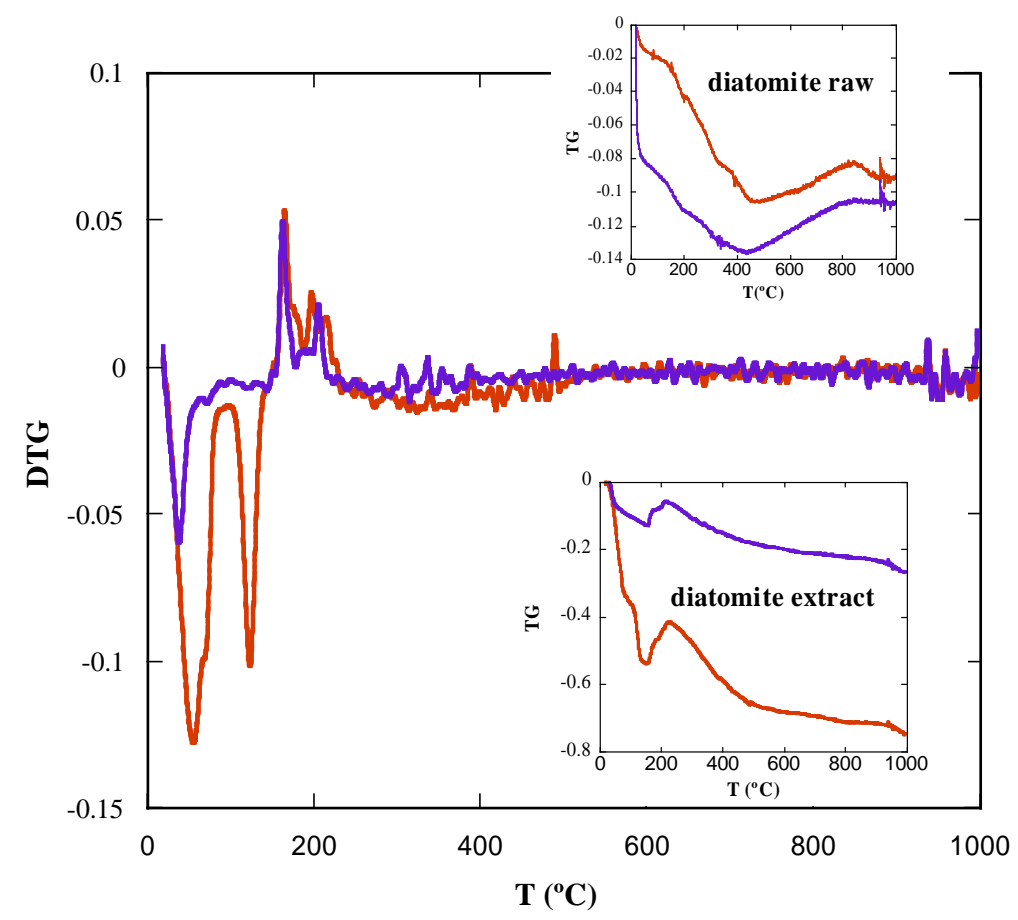

Fig. 4. Differential thermograms (DTG) of diatomite extracts. Thermograms (TG) in insets. Top: diatomites; bottom: extracts.

Furthermore, membrane filtration did not release Si or Ca and the concentrations of these elements were even reduced, especially at lower temperatures (reductions of $33.7 \%$ for $\mathrm{Si}$ and $32.8 \%$ for $\mathrm{Ca}$ at $0{ }^{\circ} \mathrm{C}$ ). A relationship between filtration temperature and the magnitude of the drop in concentration for these elements seems to exist.

\subsection{Thermograms of dry extract}

The weight losses found for the two diatomites and extracts on heating (TG) and their derivatives (DTG) are shown in Fig. 4. TG values for raw diatomites (top inset) were much lower than for the extracts (bottom inset) and this finding is consistent with the low contents of soluble compounds in diatomites (see Table 1a). Moreover, the DTG data for the calcined diatomite extract showed only one peak for temperatures below $200^{\circ} \mathrm{C}$, whereas the flux calcined diatomite extract showed two peaks, which correspond to solvent evaporation and the loss of molecular water. The weight gain in the range $200-300^{\circ} \mathrm{C}$ is due to oxidation of the extracts since the experiments were carried out in an air atmosphere. The absence of other peaks at higher temperatures indicates that other residual decompositions did not occur.

\section{Conclusion}

Diatomite is not an inert filter aid and it contains up to $0.36 \%$ by weight of compounds that are soluble in ethanol/water mixtures (36\% vol.). Of the soluble compounds present in diatomite, amorphous silica is the most abundant component and it represents $30 \%$ by weight of the extract. Calcium sulphate and some heavy metals are also present at very low levels, although the presence of such components at any level is not desirable. The extracted 
silica generates hollow spherical microparticles with an average diameter of $100 \mu \mathrm{m}$ in the ethanol/water mixture employed. Furthermore, brandy contains small amounts of silicon before filtration and, after contact with diatomite, the concentration of this element increases considerably. It was found that the calcined diatomite releases more silicon than the flux calcined diatomite. These increases in concentrations were less marked when filtration was carried out at a low temperature. In contrast, membrane filtration leads to a reduction in Si concentration and there is a relationship between temperature and the magnitude of the decrease, which can reach up to $33.7 \%$ at $0{ }^{\circ} \mathrm{C}$. Considering the potential effects of Si on spirit stability, the results described here should be considered by diatomite manufacturers and spirit producers.

\section{Appendix A. Supplementary data}

Supplementary data associated with this article can be found, in the online version, at http://dx.doi.org/10.1016/j.foodchem.2014. 02.157 .

\section{References}

Alexander, G. B., Heston, W. M., \& Iler, R. K. (1954). The solubility of amourphous silica in water. Journal of Physical Chemistry, 58, 453-455.

Bauer, K. H., Hinkel, S., Neeb, R., Eichler, P., \& Eschnauer, H. R. (1995). Silicon in wine A trace element - Vinogramme. Wein-Wissenschaft, 50(4), 118-122.

Cameán, A. M., Moreno, I., López-Artíguez Repetto, M., \& González, A. G. (2001) Differentiation of Spanish brandies according to their metal content. Talanta, 54, 53-59.

Chan, Y., Hyung, L., Sujin, C., Dae, S., \& Seung-Ho, L. (2012). Preparation of hollow silica by spray drying of nano silica particles and its heat transfer property. Korean Journal of Materials Research, 22(10), 531-538.

Dayan, A. D., \& Paine, A. J. (2001). Mechanisms of chromium toxicity, carcinogenicity and allergenicity: Review of the literature from 1985 to 2000 Human E Experimental Toxicology, 20, 439-451.

European-Union (2008). Regulation (EC) 110/2008 of the European Parliament and of the Council on the definition, description, presentation, labelling and the protection of geographical indications of spirit drinks and repealing Council Regulation (EEC) No 1576/89. Official Journal of the European Union, L 39, 16-54.

Fatoni, A., Koesnarpadi, S., \& Hidayati, N. (2010). Synthesis, characterization and application of diatomaceous earth - 4,4-diaminophenylether-Ohydroxybenzaldehyde as an adsorbent of $\mathrm{Ag}(\mathrm{I})$ metal ion. Indonesian Journal of Chemistry, 10(3), 315-319.

Gómez-Benítez, J. (1992). Stability of Jerez Brandy. Vitivinicultura, 2, 46-50.

Gunnarsson, I., \& Arnorsson, S. (2000). Amorphous silica solubility and the thermodynamic properties of $\mathrm{H}_{4} \mathrm{SiO}^{\circ} 4$ in the range of $0^{\circ}$ to $350{ }^{\circ} \mathrm{C}$ at Psat. Geochimica E' Cosmochimica Acta, 64(13), 2295-2307.

Ibanez, J. G., Carreon-Alvarez, A., Barcena-Soto, M., \& Casillas, N. (2008). Metals in alcoholic beverages: A review of sources, effects, concentrations, removal, speciation, and analysis. Journal of Food Composition and Analysis, 21, 672-683.

Iler, R. K. (1979). The chemistry of silica. New York.
Inglethorpe, S. D. J. (1993). Diatomite. Industrial minerals laboratory manual. In Technical Report WG/92/39. Mineralogy and petrology series (pp. 1-37). Nottingham: Natural Environment Research Council.

Interesse, F. S., Lamparelli, F., \& Alloggio, V. (1984). Mineral contents of some southern Italian wines. I. Determination of boron, aluminum, silicon, titanium, vanadium, chromium, manganese, iron, nickel, copper, zinc, molybdenum, tin, lead by inductively coupled plasma atomic emission spectrometry (ICP-AES). Zeitschrift fuer Lebensmittel-Untersuchung und -Forschung, 178(4), 272-278.

Jodral-Segado, A. M., Navarro-Alcorcón, M., López-García de la Serrana, H., \& LópezMartínez, M. C. (2003). Magnesium and calcium contents in foods from SE Spain: Influencing factors and estimation of daily dietary intakes. The Science of the Total Environment, 312, 47-58.

Jugdaohsingh, R., O'Connell, M. A., Sripanyakorn, S., \& Powell, J. J. (2006). Moderate alcohol consumption and increased bone mineral density: Potential ethanol and non-ethanol mechanisms. Proceedings of the Nutrition Society, 65, 291-310.

Jugdaohsingh, R., Tucker, K. L., Qiao, N., Cupples, L. A., Kiel, D. P., \& Powell, J. J. (2004). Dietary silicon intake is positively associated with bone mineral density in men and premenopausal women of the Framingham Offspring cohort. Journal of Bone and Mineral Research, 19, 297-307.

Junta-de-Andalucia (2005). Order of June 132005 approving the regulation of the Specific Appelation "Brandy de Jerez" and its Regulatory Council. BOJA, 122, $38-45$.

Kadey, F. L. (1975). Diatomite. In S. J. Lefond (Ed.), Ind. miner. rocks (4th ed., pp. 605635).

Liangjuan, G., \& Junhui, H. (2013). Surface hydrophobic co-modification of hollow silica nanoparticles toward large-area transparent superhydrophobic coatings. Journal of Colloid and Interface Science, 396(396), 152-159.

Marshall, W. L., \& Warakomski, J. M. (1980). Amorphous silica solubiities-II. Effect of aqueous salt solutions at 25"C. Geochemistry and Cosmochemistry Acta, 44, 915-924.

Martin, K. R. (2007). The chemistry of silica and its potential health benefits. The Journal of Nutrition, Healt and Aging, 11(2), 94-98.

Martinovic, S., Vlahovic, M., Boljanac, T., \& Pavlovic, L. (2006). Preparation of filter aids based on diatomites. International Journal of Mineral Processing, 80(2-4), 255-260.

OIV (2006). DIATOMITE.OENO 10/2002. In International Oenological Codex. Paris.

Park, S., Kim, Y., \& Park, S. (2008). Size-dependent shape evolution of silica nanoparticles into hollow structures. Langmuir, 24(21), 12134-12137.

Powell, J. J., McNaughton, S. A., Jugdaohsingh, R., Anderson, S. H. C., Dear, J., Khot, F., et al. (2005). A provisional database for the silicon content of foods in the United Kingdom. British Journal of Nutrition, 94, 804-812.

Rodríguez-Mercado, J. J., \& Altamirano-Lozano, M. A. (2006). Vanadio: Contaminación, metabolismo y genotoxicidad. Revista Internacional de Contaminación Ambiental, 22(4), 173-189.

Ruzic, N. E., \& Puskas, V. S. (2001). Effect of some filtering materials on heavy metals content in wine. Acta Periodica Technologica, 32, 27-32.

Schwarz, M. Rodriguez, M. C., Guillen, D. A., \& García, C. (2011). Analytical characterisation of a Brandy de Jerez during its ageing. European Food Research and Technology, 232(5), 813-819.

Seidel, A., Liibbus, M., Vogelsberger, W., \& Sonnefeld, J. (1997). The kinetics of dissolution of silica 'Monospher' into water at different concentrations of background electrolyte. Solid State Ionics, 101-103, 713-719.

Van Cappellen, P., \& Qiu, L. (1997). Biogenic silica dissolution in sediments of the Southern Ocean. I. Solubility. Deep Sea Research II, 44(5), 1109-1128.

Wang, L. K. (2006). Diatomaceous earth precoat filtration. In Handbook of Environmental Engineering (pp. 155-189).

Wen-Tien, T., Chi-Wei, L., \& Kuo-Jong, H. (2006). Characterization and adsorption properties of diatomaceous earth modified by hydrofluoric acid etching. Journal of Colloid and Interface Science, 297, 749-754. 